\title{
Indigenous knowledge of Rural Communities for Combating Climate Change Impacts in West Central Ethiopia
}

https://dx.doi.org/10.4314/jae.v22i1.16

\author{
Amare, Zerihun Yohannes \\ Pan African University, Life and Earth Sciences Institute (Including Health and Agriculture), \\ PAULESI, University of Ibadan, Ibadan, Nigeria. \\ E-mail address: zerihun.yohannes19@gmail.com; Phone: +234-8057332400/+251- \\ 913450741
}

\begin{abstract}
The study examined how local knowledge of climate change plays a role in adjusting to changing climate and how these beliefs may influence future decision making about how to go about adjusting to climate change at a local level. The study was conducted in west central Ethiopia at the edge of the Blue Nile. The current indigenous knowledge practiced by the local community in adopting the changing environmental conditions was discussed. Rural communities have local knowledge in areas such as weather and seasonal forecasting (44\%), drought forecasting (20.9\%), crop pest \& disease (47\%), and weed (99.7\%) control methods to adapt to some of the climate change impacts. Not all households have the same levels and types of indigenous knowledge. Therefore, awareness creation and experience sharing among community members are important in increasing the application of indigenous knowledge for climate change adaptation.
\end{abstract}

Keywords: Climate change adaptation, Climate change impacts, Ethiopia, Indigenous knowledge

\section{Introduction}

East Africa is one of the most food insecure regions in Africa due to frequent climate risks (Slegers and Stroosnijder, 2008, Demeke et al., 2011, Gray and Mueller, 2012). Ethiopia faces numerous development challenges that exacerbate its vulnerability to climate change, including food insecurity and ongoing conflict over natural resources such as water and grazing lands. The climate change variables such as an increase in temperature, and rainfall variation lead an increase in crop pest and disease outbreaks and other extreme events like a flood. In Ethiopia, climate change affects agriculture, water, and human health. Local peoples knowledge was acknowledged in the Fourth Assessment Report of the Intergovernmental Panel on Climate Change (IPCC) as 'an invaluable basis for designing adaptation, coping, and natural resource management strategies in response to environmental and other forms of change'(IPCC, 2007, Nakashima et al., 2012). 
Creative commons User License: CC BY-NC-ND

Abstracted by: EBSCOhost, Electronic Journals Service (EJS), Google Scholar, Journal Seek, Scientific Commons,

Food and Agricultural Organization (FAO), CABI and Scopus
Journal of Agricultural Extension

Vol. 22 (1) February, 2018

ISSN(e): 24086851; ISSN(Print); $1119944 X$

http://journal.aesonnigeria.org

http://www.aiol.info/index.php/iae

Email: editorinchief@aesonnigeria.org

Combating climate change impact requires the involvement of many people ranging from communities who experience the effects on a daily basis, to scientists attempting to understand the biophysical and socioeconomic causes and consequences of climate change, to developers and policy makers at all levels. Rural communities in Sub-Saharan Africa developed several adaptation strategies that have enabled them to reduce vulnerability to climate variability and extremes. These local adaptation strategies were to conserve carbon in farming soils using zero tilling in cultivation, mulching, and other soil management techniques(Schafer et al., 1989, Osunade, 1994).

Local farmers largely depend on organic farming, which also is capable of reducing greenhouse gas emissions. It is also recognized that forests play an important role in the global carbon cycle by sequestering and storing carbon(Karjalainen et al., 1994, Stainback and Alavalapati, 2002). Application of mulching regulates soil temperatures and extremes, suppress diseases and crop pests and usd to conserve soil moisture so as to increase the productivity of agricultural land.

Indigenous knowledge refers to the knowledge and know-how accumulated across generations and renewed by each new generation, which guides human societies in their innumerable interactions with their surrounding environment (Nakashima et al., 2012). Communities indigenous knowledge has been defined as institutionalized local knowledge that has been built upon and passed on from one generation to the other by word of mouth(Ajani et al., 2013). Local peoples' knowledge focuses on elements of significance for local livelihoods, security, and well-being, and as a result, it is essential for climate change adaptation strategy. Despite the fact that indigenous knowledge is an emerging area of interest for climate change scientists, the exchange of knowledge between scientists and indigenous peoples dates back to the very origins of science (Nakashima et al., 2012). The importance of local knowledge has been known in the design and implementation of sustainable development projects; little has been done to include this into formal climate change adaptation strategies(Ziervogel and Opere, 2010).Managing climate chanage impcats has traditionally been the responsibility of households, except large extreme weather events and disasters. Improving farmers' knowledge and their capacity to observe and experiment is an essential element in the development of integrated soil fertility management technologies (Deugd et al., 1998, Corbeels et al., 2000, Heltberg et al., 2009). It is also important to establish local systems of knowledge, as they relate to specific locations and are based on experience and understanding of local conditions of production. Therefore, traditional knowledge practices embody local adaptive management to the changing environment and complement scientific research. Besides, the uncertainty associated with climate change demands an approach that prepares people without relying on detailed weather information and climate projections. In the last decades, Ethiopia has been implementing a community level environmental rehabilitation programme that focused on soil and water conservation(Ajani et al., 2013). This is a testimony that climate change impact adaptation policies should be considered part of the sustainable development process and be implemented at the grassroot level. Therefore, having the experience of this indigenous knowledge practices in climate change adaptation is important. The study 
Creative commons User License: CC BY-NC-ND

Abstracted by: EBSCOhost, Electronic Journals Service (EJS),

Google Scholar, Journal Seek, Scientific Commons,

Food and Agricultural Organization (FAO), CABI and Scopus
Journal of Agricultural Extension

Vol. 22 (1) February, 2018

ISSN(e): 24086851; ISSN(Print); 1119944X

http://journal.aesonnigeria.org

http://www.ajol.info/index.phpliae

Email: editorinchief@aesonnigeria.org

therefore was designed to assess the indigenous knowledge of rural communities to combating climate change impacts in west central Ethiopia.

\section{Aim and Objectives of the study}

The general aim of the study was to assess the indigenous knowledge of rural communities to combating climate change impacts in west central Ethiopia.

\section{The specific Objectives were to:}

1. Explore the current weather and seasonal forecasting knowledge of the rural communities

2. Identify the current soil fertility increment techniques and seasonal food shortage coping methods

3. Identify the current pest, disease, and weed control methods

\section{Methodology}

The study was conducted in Dejen district of west-central Ethiopia at a road distance of $335 \mathrm{~km}$ south of the regional state capital, BahirDar, and $230 \mathrm{~km}$ northwest of the capital city of Ethiopia, Addis Ababa. The district lies between longitude $38^{\circ} 6^{\prime} \mathrm{E}$ and $38^{\circ} 10^{\prime} \mathrm{E}$, and between latitude $10^{\circ} 7^{\prime} \mathrm{N} 10^{\circ} 11^{\prime} \mathrm{N}$, with an elevation of 1071 and 3000 meters above sea level (>M.A.S.L). The same to most parts of Ethiopia; it is a mixed production system with both crop and livestock rearing. Crop production is completely rainfed, except in a small number of localities where small-scale water harvesting processes have been recently introduced by the office of Agriculture and Rural Development. In the lowland parts of the district, the combination of moisture stress and poor soil fertility is the limiting factor for agricultural production. The climate of the district is traditionally classified based on altitude and temperature. Annual average temperature and total annual rainfall of the district range between $20^{\circ} \mathrm{C}$ and $24^{\circ} \mathrm{C}$ and $800 \mathrm{~mm}$ and 1200 millimetres, respectively. The district has been categorised into three traditional climatic zones, 41\%, highland,31 \% midland, and $28 \%$ lowland(DDFEDO, 2014, DDEPO, 2016).

The data were collected between March to October 2016 in the three agro-ecological settings of lowland, midland, and highland sites of the Nile basin of Ethiopia. This was because climate change affects the rural communities differently in different agroecological zones. As a result, communities' knowledge and skill to adapt to the climate change impacts varies from place to place. Stratified and snowball sampling techniques were employed to select a sample of 398 households. The household survey was employed to collect data on households' local knowledge to adapt climate change impacts and time series climate data over the period 1979-2014 was used to triangulate the households' response respectively. Focus group discussions and key informant interviews were used to triangulate households' response on local knowledge of climate change adaptation strategies. Field observations were used to observe biophysical, economic, social, and institutional features of the district. The indigenous knowledge of households was measured using variables such as 
Creative commons User License: CC BY-NC-ND

Abstracted by: EBSCOhost, Electronic Journals Service (EJS),

Google Scholar, Journal Seek, Scientific Commons,

Food and Agricultural Organization (FAO), CABI and Scopus
Journal of Agricultural Extension

Vol. 22 (1) February, 2018

ISSN(e): 24086851; ISSN(Print); 1119944X

http://journal.aesonnigeria.org

http://www.ajol.info/index.phpliae

Email: editorinchief@aesonnigeria.org

traditional weather forecasting knowledge, knowledge of households in predicting the quality of the coming season (rain or drought), traditional climate change impact coping and adaptation strategies such as water and land resource management, pest control methods, weed control methods, and seasonal food shortage coping mechanisms. Seasonal rainfall is the major determinants of Ethiopian agricultural production. Ethiopia has three seasons; KIREMT which is the main rain season (June to September), BEGA, characterized by sunny and dry weather situation with occasional falls. It extends from October to January and BELG which is the small rainy season that extends from February to May and covers Southern, Central, Eastern and North eastern parts of the country. Hence rain-fed agriculture is highly dependent on rainfall patterns, the rural communities have to make crucial decisions about sowing time and the varieties of crops used. In both agro-ecology of the district, people make these decisions on the basis of their observations of what they call "signs" of the weather forecast.

The results from surveyed households and focus group discussions revealed, farmers use and rely on indigenous knowledge forecasts than on scientific weather forecasts. This is because of lack of tailored made information as per their understanding and insufficient information from the National Meteorological Agency of Ethiopia. These responses were analysed using statistical product and service solutions (SPSS version20). The household survey questions that used in collecting indigenous knowledge of rural communities were open ended.

\section{Results and Discussion}

The results were structured to reflect the local communities' knowledge of coping and adaptation strategies of climate change impacts.

\section{Weather and Seasonal Forecasting Knowledge}

Farmers tend to use a combination of indigenous knowledge and scientific information in their seasonal forecasting, as they primarily rely on indigenous knowledge but are also open to receiving scientific forecasts from their district agricultural office experts.

About $44 \%$ of the farmers had forecasting knowledge. Signs (indicators) used to forecast the start and end of rain season and weather forecasts include moisturized wind from North to South (31.9\%) which shows onset of short rainy season and sign of heavy rainfall in the coming season, unusual heat increment $(11.1 \%)$ and lighting towards East $(16.1 \%)$ indicating to rain within late afternoon. Others include when the sky becomes clean $(0.5 \%)$, there will be rain within a week period. The sound of Eagle $(0.5 \%)$ also shows the coming season will be rainy/Belg (Figure 1$)$. Previous studies have reported signs such as "winds blow from North to South(Risiro et al., 2012) and feeling of excess heat during the night and day(Risiro et al., 2012, Mahoo et al., 2015) 
Creative commons User License: CC BY-NC-ND

Abstracted by: EBSCOhost, Electronic Journals Service (EJS), Google Scholar, Journal Seek, Scientific Commons,

Food and Agricultural Organization (FAO), CABI and Scopus
Journal of Agricultural Extension

Vol. 22 (1) February, 2018

ISSN(e): 24086851; ISSN(Print); $1119944 X$

http://journal.aesonnigeria.org

http://www.ajol.info/index.php/iae

Email: editorinchief@aesonnigeria.org

\begin{tabular}{|c|c|c|c|c|c|}
\hline \multirow{4}{*}{ 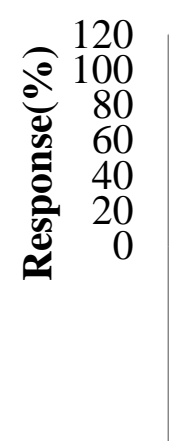 } & & \multirow[b]{4}{*}{$\begin{array}{l}\text { when there is } \\
\text { unusual heat } \\
\text { increament }\end{array}$} & \multirow[b]{4}{*}{$\begin{array}{l}\text { when lighting } \\
\text { towards East }\end{array}$} & \multirow[b]{4}{*}{$\begin{array}{c}\text { When the sky } \\
\text { becomes } \\
\text { clean }\end{array}$} & \multirow[b]{4}{*}{$\begin{array}{c}\text { When we } \\
\text { heared the } \\
\text { sound of } \\
\text { Eagle }\end{array}$} \\
\hline & \multirow[b]{3}{*}{$\begin{array}{l}\text { Moisturised } \\
\text { wind blown } \\
\text { from north to } \\
\text { south }\end{array}$} & & & & \\
\hline & & & & & \\
\hline & & & & & \\
\hline Yes & 31.9 & 11.1 & 16.1 & 0.5 & 0.5 \\
\hline No & 68.1 & 88.9 & 83.9 & 99.5 & 99.5 \\
\hline
\end{tabular}

Figure 1: Households rainfall forecasting knowledge Household Survey data, March-October (2016)

The communities have also drought forecasting knowledge. A few $(20.9 \%)$ of respondents have indigenous drought forecasting knowledge. Identified local knowledge for drought forecast include: there is drought in every four years $(2.3 \%)$, when there is dry fog $(10.1 \%)$, North to South dry wind (12.3\%) and the wind after some rainy days $(0.5 \%)$ were indicators for a bad season in the rural communities (Figure 2).

The study communities believe there is a drought in every four years. This result coincides with the focus group discussions, the key informant interviews, and the results of climate data analysis precipitation index (SPI). In the past ten years (2005 to 2014), there were two drought years in every four years. The year 2008 was characterized by severe drought and 2012 extreme drought (see Table1). The table showed 12 months of above and below normal wet and dry seasons from the 36 years. Local communities in Africa have continued to rely on indigenous knowledge to conserve the environment and deal with natural disasters such as drought (Chang'a et al., 2010, Egeru, 2012, Mahoo et al., 2015).

\section{Table1: Standardized precipitation index(SPI) values of above and below} normal wet and dry years

\begin{tabular}{cccc}
\hline Years & Annual rainfall $(\mathrm{mm})$ & SPI values & Values Category \\
\hline 1983 & 1251.4 & 1.2 & Moderately wet \\
1986 & 1269.6 & 1.29 & Moderately wet \\
1987 & 1363.6 & 1.71 & Moderately wet \\
1996 & 1274.94 & 1.31 & Moderately wet \\
1998 & 1403.3 & 1.89 & Moderately wet \\
2002 & 467.6 & -2.35 & Extremely dry \\
2008 & 713.6 & -1.24 & Moderately dry \\
2010 & 1274.1 & 1.31 & Moderately wet \\
2011 & 686.6 & -1.36 & Moderately dry \\
2012 & 536.04 & -2.04 & Extremely dry \\
2013 & 699.6 & -1.3 & Moderately dry \\
2014 & 759.15 & -1.03 & Moderately dry \\
\hline
\end{tabular}

Computed from global weather data for soil and water assessment [http://globalweather.tamu.edu/]1979-2014) 
Creative commons User License: CC BY-NC-ND

Abstracted by: EBSCOhost, Electronic Journals Service (EJS),

Google Scholar, Journal Seek, Scientific Commons,

Food and Agricultural Organization (FAO), CABI and Scopus
Journal of Agricultural Extension

Vol. 22 (1) February, 2018

ISSN(e): 24086851; ISSN(Print); 1119944X

http://journal.aesonnigeria.org

http://www.ajol.info/index.php/iae

Email: editorinchief@aesonnigeria.org

Less than half (44\%) of respondents have weather and seasonal forecasting knowledge and only $20.9 \%$ of respondents have traditional drought forecasting knowledge. This implies that not all households have the same levels and types of indigenous knowledge. Therefore, awareness creation and experience sharing among community members are important in increasing the application of indigenous knowledge as a climate change adaptation.

\begin{tabular}{|c|c|c|c|c|}
\hline \multirow{4}{*}{ 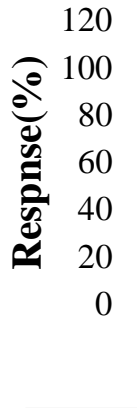 } & & & & \\
\hline & & & & \\
\hline & & & & \\
\hline & $\begin{array}{c}\text { There is drought in } \\
\text { every } 4 \text { yrs }\end{array}$ & $\begin{array}{c}\text { When there is dry } \\
\text { fog }\end{array}$ & $\begin{array}{c}\text { North to South } \\
\text { Wind }\end{array}$ & $\begin{array}{l}\text { Wind after some } \\
\text { rainy days }\end{array}$ \\
\hline - Yes & 2.3 & 10.1 & 12.3 & 0.5 \\
\hline $\mathrm{No}$ & 97.7 & 89.9 & 87.7 & 99.5 \\
\hline
\end{tabular}

Figure 2: Drought forecasting knowledge of households

Household Survey data, March-October (2016) 
Creative commons User License: CC BY-NC-ND

Abstracted by: EBSCOhost, Electronic Journals Service (EJS),

Google Scholar, Journal Seek, Scientific Commons,

Food and Agricultural Organization (FAO), CABI and Scopus
Journal of Agricultural Extension

Vol. 22 (1) February, 2018

ISSN(e): 24086851; ISSN(Print); 1119944X

http://journal.aesonnigeria.org

http://www.ajol.info/index.phpliae

Email: editorinchief@aesonnigeria.org

Table 2: Weather and drought forecasting knowledge of rural communities

\begin{tabular}{|c|c|c|c|}
\hline & \multicolumn{2}{|c|}{ Responses } & Agro- \\
\hline $\begin{array}{l}\text { Discussed } \\
\text { issues }\end{array}$ & Female FGDs & Male FGDs & \\
\hline $\begin{array}{l}\text { weather } \\
\text { forecasting } \\
\text { knowledge }\end{array}$ & $\begin{array}{l}\text { There is rain when lightning } \\
\text { towards East }\end{array}$ & $\begin{array}{l}\text { When there is un usual heat, } \\
\text { the rain will come in the late } \\
\text { afternoon or evening time of } \\
\text { the day }\end{array}$ & Highland \\
\hline $\begin{array}{l}\text { drought } \\
\text { forecasting } \\
\text { knowledge }\end{array}$ & $\begin{array}{l}\text { When there is rain at the end of rain } \\
\text { season (September 11), it is } \\
\text { expected to be good for the coming } \\
\text { season and vice versa. }\end{array}$ & $\begin{array}{l}\text { There is drought in every four } \\
\text { years }\end{array}$ & \\
\hline $\begin{array}{l}\text { weather } \\
\text { forecasting } \\
\text { knowledge }\end{array}$ & $\begin{array}{l}\text { When there is un usual heat, the } \\
\text { rain will come } \\
\text { There is rain when lightning } \\
\text { towards East and vice versa }\end{array}$ & $\begin{array}{l}\text { When we hear sound of Eagle, } \\
\text { the rain will come not later than } \\
\text { a week } \\
\text { When the wind blows from west } \\
\text { to East, rain will come }\end{array}$ & Midland \\
\hline $\begin{array}{l}\text { drought } \\
\text { forecasting } \\
\text { knowledge }\end{array}$ & They have no idea & $\begin{array}{l}\text { There is drought in every four } \\
\text { years }\end{array}$ & \\
\hline $\begin{array}{l}\text { weather } \\
\text { forecasting } \\
\text { knowledge }\end{array}$ & $\begin{array}{l}\text { There is rain when lightning } \\
\text { towards East }\end{array}$ & $\begin{array}{l}\text { When there is un usual heat, } \\
\text { the rain will come } \\
\text { There is rain when lightning } \\
\text { towards East }\end{array}$ & Lowland \\
\hline $\begin{array}{l}\text { drought } \\
\text { forecasting } \\
\text { knowledge }\end{array}$ & They have no idea & $\begin{array}{l}\text { April Rain is a good indicator of } \\
\text { good season }(B e l g) \\
\text { When there is left side wind, } \\
\text { there will be frost with } \\
\text { consequence of crop failure } \\
\text { specifically cereal crops and } \\
\text { red pepper } \\
\text { There is drought in every four } \\
\text { years }\end{array}$ & \\
\hline
\end{tabular}

\section{Focus group discussions (FGDs), August (2016)}

\section{Soil Fertility Increment Techniques and Seasonal Food Shortage Coping Mechanisms}

Rural communities have their own indigenous knowledge of classifying, describing and characterizing local soil types in their farmlands based on the soils characteristics and its suitability for growing various types of crops. Farmers identified different soil types based on their colour, stony composition, water holding capacity, the capacity of the soil for long-term productivity of crop yield, drainage \& manure requirement of the farmland and topographic location (cultivability). The majority (95.7\%) of respondents have at least one traditional soil fertility increment techniques such as use of compost, animal waste, frequent ploughing, terracing, crop rotation, leguminous plants, and fallowing (Figure3). Seasonal migration and shift to cheap food items were some of seasonal food shortage coping mechanisms. 
Creative commons User License: CC BY-NC-ND

Abstracted by: EBSCOhost, Electronic Journals Service (EJS),

Google Scholar, Journal Seek, Scientific Commons,

Food and Agricultural Organization (FAO), CABI and Scopus
Journal of Agricultural Extension

Vol. 22 (1) February, 2018

ISSN(e): 24086851; ISSN(Print); 1119944X

http://journal.aesonnigeria.org

http://www.ajol.info/index.phpliae

Email: editorinchief@aesonnigeria.org

Manure-compost: The majority $(92.3 \%)$ of farming households and non-farming households who have backyard apply manure-compost to increase their farm/backyard land fertility. Compost is a mix of animal wastes and a variety of organic materials such as leaves, grass clippings, kitchen scraps and yard wastes. As a result, it takes time to prepare and requires labour. The respondents report that composting takes up to six to eight months to get ready for the farm. Whereas, among those who did not use manure-compost, $35.7 \%$ of them explained, they did not have skill to make compost, shortage of labour(21.4\%), small land/no land at all (39.3\%) to apply manure, insignificant numbers of households(3.6\%) have doubt on manure-compost to increase soil fertility.

Frequent ploughing: Only $0.8 \%$ use frequent ploughing. In the study area, frequent ploughing is not only to increase soil fertility, it also uses to expose to sun light weed residuals and kill crop pests and diseases. The reason for non-use by many farmers was due to it is labour intensiveness and cost.

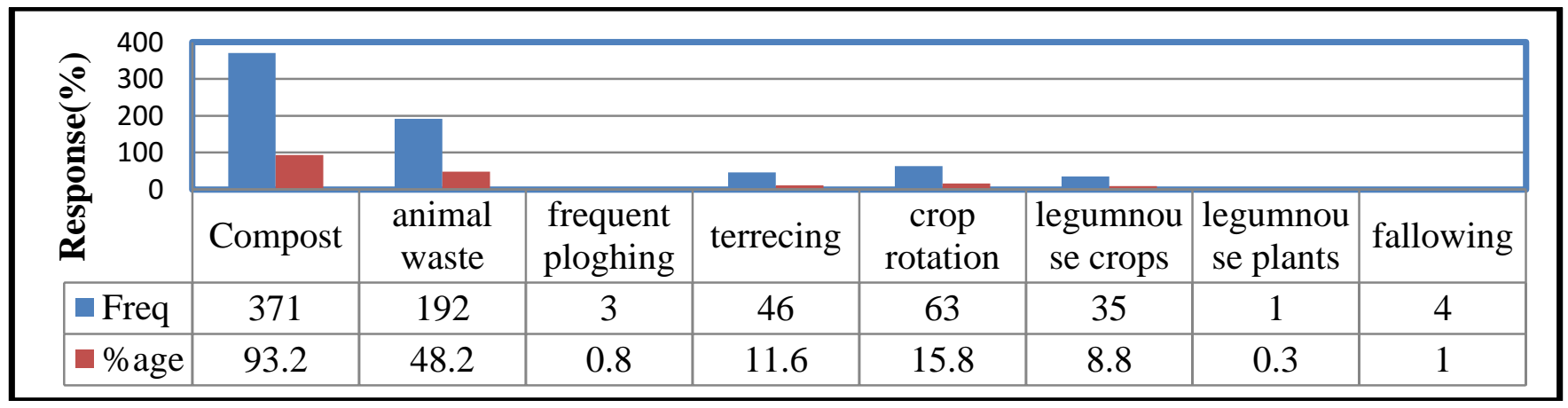

Figure 3: Traditional soil fertility increment techniques

Household Survey data, March-October (2016)

Terracing: Farmers traditionally constructed terraces (11.6\%) to improve soil fertility and productivity. In addition to soil fertility, terracing the low land helps to slow down water runoff and capture sediments. Farmers regard these sediments as fertile soil material and believe that terracing can make an infertile soil more fertile specifically on the hill sides of the study sites.

Crop rotation: About $16 \%$ of the respondents practiced crop rotation to increase the fertility of their soil. Major crop rotations practiced by farmers' choice were; barelywhat-teff/maize; teff-barely-wheat; barely-chicken pea-barely.

Leguminous crops and plants: A few of the respondents adopted use of leguminous crops $(8.8 \%)$ and plants $(0.3 \%)$ as methods of enhancing soil fertility and adapting to climate change. Some of the leguminous crops are beans and peas. Besides soil fertility increment, leguminous plants such as alfalfa were used as fodder for animals. These legumes can increase soil fertility and reduce weeds by conserving organic matters. Ayoade (1983) noted that, legumes and grasses could increase soil fertility and controls weeds with the addition of organic matter and improve the water retention capacity of the soil.

Fallowing: Very few farmers (1\%) used this system to increase their soil fertility. Limited extension services and weather information, lack of skills, lack of water, 
Creative commons User License: CC BY-NC-ND

Abstracted by: EBSCOhost, Electronic Journals Service (EJS),

Google Scholar, Journal Seek, Scientific Commons,

Food and Agricultural Organization (FAO), CABI and Scopus
Journal of Agricultural Extension

Vol. 22 (1) February, 2018

ISSN(e): 24086851; ISSN(Print); 1119944X

http://journal.aesonnigeria.org

http://www.ajol.info/index.phpliae

Email: editorinchief@aesonnigeria.org

shortages of land and land fragmentation have led the insufficient application of traditional soil fertility management practices such as fallowing.

Seasonal migration: In Ethiopia labours often move to in another place for seasonal work and destinations and work vary by community members. Young people and some household owners often seek alternate and seasonal sources of income especially during crop failure and other shocks. However, seasonal migration in the government extension package is not included as adaptation strategies in the study area. Each year during the dry season following harvest people from many communities in rural Ethiopia travel for temporary work. On the contrary, the majority $(67.4 \%)$ of the surveyed households were reluctant to leave their locality even for a day period. This was due to their family love and cares each other in the nearby $(67.4 \%)$ and culturally (6.2\%) did not want to travel outside their locality as they think it as migrant. Others explain the shortage of labour (14\%) to travel seasonally and work, do not have skills and information (11.4\%) about where and how to travel and work. Insignificant numbers of households (0.8\%) explain the lack of money for transportation.

Shift to cheaper food items: The other seasonal food shortage coping mechanism was changing household consumption to cheap food items. During climatic shocks $71.8 \%$ of the surveyed households shift their daily consumption to less expensive items. In Ethiopia Teff is the major food crop and that used as household food consumption in urban and rural communities. As a result, the communities take as a culture and relying on it. The same to this, among those who did not change $(28.2 \%)$ their food items to cheaper food crops during the bad time or drought shocks, explained that it is because of the culture of consumption $(77.7 \%)$ of households relying on one or two food crops. Others $(22.3 \%)$ did not have information about changing /shifting to cheap food items.

\section{Pest, Disease, and Weed Control Techniques}

About $47 \%$ have at least one type of traditional crop pest and disease control technique. Climate change could have positive, negative or no impact on each pest. There is a need for better models to assess their global impact as most pest population prediction models have different spatial and temporal scales than global models (Reijntjes et al., 1992, Ajani et al., 2013). Crop pests are usually controlled by cultural practices, natural enemies, host plant resistance, biopesticides, and synthetic pesticides. However, many of these control methods are highly sensitive to the environment and climate change may render them less effective. For example, there were indications that stem rot (Sclerotium rolfsii) resistance in groundnut is temperature dependent, while in Kenya resistance to sorghum midge(Stenodiplosis sorghicola) breaks down under high humidity and moderate temperatures (Ajani et al., 2013). The traditional techniques used for pest control include application of livestock urine and wood ash(31.4\%), mix of different leaves(14.3\%) such as clematishirsuta (Yeazohareg),crotonmacrostachyus (Bisana) Eucalyptus leaves, flooding over the affected land $(0.8 \%)$,spraying boiled water $(0.3 \%)$, frequent ploughing $(0.8 \%)$,burning of crop residuals $(2.5 \%)$, clearing of leaves around farmland (1.8\%), disturb the pests 
Creative commons User License: CC BY-NC-ND

Abstracted by: EBSCOhost, Electronic Journals Service (EJS),

Google Scholar, Journal Seek, Scientific Commons,

Food and Agricultural Organization (FAO), CABI and Scopus
Journal of Agricultural Extension

Vol. 22 (1) February, 2018

ISSN(e): 24086851; ISSN(Print); 1119944X

http://journal.aesonnigeria.org

http://www.ajol.info/index.php/jae

Email: editorinchief@aesonnigeria.org

using stick manually (4.5\%), removing affected plants $(0.8 \%$ and covering seeds with leaves and wood ash(0.5\%) can be used to kill crop pests and diseases(Table3).

The majority (99.7\%) of households have at least one traditional weed control methods. $99.5 \%$ used hand weeding, a few $(9.3 \%)$ used burning of residuals, frequent ploughing (20.6\%) and use of improved seeds (2.3\%) (Figure 4). Burning of residuals after harvest can reduce the surface seed banks and destroy weed seeds. However, burning of crop residuals has the potential to increase greenhouse gases which has a great contribution for climate change(Amare, 2014). Thus, before adopting such indigenous knowledge practices need to be examined for their appropriateness just as any other technology. Both the soil fertility increment, pest and disease control techniques are in line with results obtained from focus group discussions (Table4). Scott et al. (2014) noted that, the main drivers for climate change impacts on plants, including weeds are a change in temperatures and rainfall, altered frequency and intensity of extreme weather events and climate change exacerbate both the threat to biodiversity and the cost of agriculture weeds.

Table 3: Crop pest and disease control techniques used by rural households

\begin{tabular}{lllllllllll}
\hline $\begin{array}{l}\text { Respo } \\
\text { nses } \\
(\%)\end{array}$ & $\begin{array}{l}\text { Mix of } \\
\text { livestock } \\
\text { urine } \\
\text { \&wood } \\
\text { ash }\end{array}$ & $\begin{array}{l}\text { Mix of } \\
\text { different } \\
\text { leaves }\end{array}$ & $\begin{array}{l}\text { Flooding } \\
\text { over } \\
\text { farmland }\end{array}$ & $\begin{array}{l}\text { Sprayin } \\
\text { g boiled } \\
\text { water }\end{array}$ & $\begin{array}{l}\text { Frequent } \\
\text { ploughing }\end{array}$ & $\begin{array}{l}\text { Burning of } \\
\text { residues }\end{array}$ & $\begin{array}{l}\text { Cleari } \\
\text { ng of } \\
\text { leave } \\
\text { s }\end{array}$ & $\begin{array}{l}\text { Disturb } \\
\text { by } \\
\text { stick }\end{array}$ & $\begin{array}{l}\text { Removin } \\
\text { affected } \\
\text { plant }\end{array}$ & $\begin{array}{l}\text { Covering } \\
\text { seed with } \\
\text { leaves \& } \\
\text { wood ash }\end{array}$ \\
\hline Yes & 31.4 & 14.3 & 0.8 & 0.3 & 0.8 & 2.5 & 1.8 & 4.5 & 0.8 & 0.5 \\
No & 68.6 & 85.7 & 99.2 & 99.7 & 99.2 & 97.5 & 98. & 95.5 & 99.2 & 99.5 \\
\hline
\end{tabular}

Household Survey data, March-October (2016)

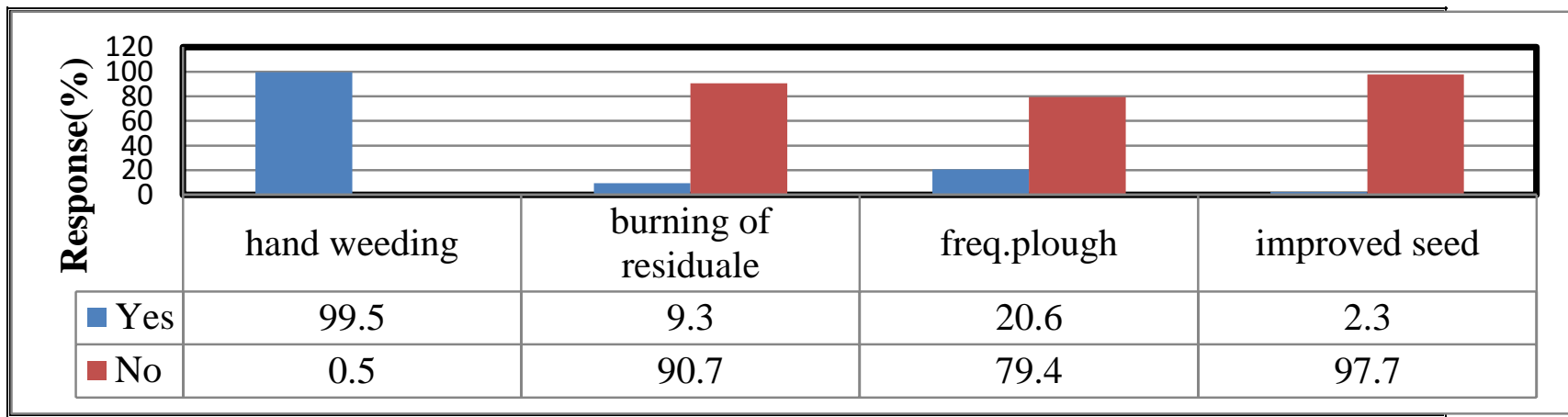

Figure 4: Crop weeds control techniques Household Survey data, March-October (2016)

The focus group discussions reveals that grass/vegetation strip along with conservation tillage and hoeing improves crop yields by reducing run-off and top soil erosion (Table4). Studies conducted by Zhang et al. (2004) and Zhang et al. (2009) in hilly areas of the Sichuan Basin where manual hoeing is a predominant tillage method 
Creative commons User License: CC BY-NC-ND

Abstracted by: EBSCOhost, Electronic Journals Service (EJS),

Google Scholar, Journal Seek, Scientific Commons,

Food and Agricultural Organization (FAO), CABI and Scopus

\section{Journal of Agricultural Extension}

Vol. 22 (1) February, 2018

ISSN(e): 24086851; ISSN(Print); 1119944X

http://journal.aesonnigeria.org

http://www.aiol.info/index.php/iae

Email: editorinchief@aesonnigeria.org

demonstrated that, tillage erosion rates by contour tillage were reduced by $77 \%$, compared to those for down slope tillage. Tillage erosion is the downslope movement of soil by tillage. That means during tillage, soil is lifted and gravity moves soil downslope. This implies, grass/vegetation strip has a role in reducing erosion for the downslope farming locations. Besides, changing other types of seed produced from another farm and sowing seeds in mud farm are weeds control techniques in the study area. Farmers believe that seeds from another farmland have a strong adaptive capacity to weeds for the new farmland.

Religion plays a role in local adaptation strategies. Old age and being the religious head is an important determinant to understand and interpret indigenous knowledge to climate change impacts. In bad years /season, communities come together in church or the mosques and pray for better rains. Praying and spraying holy water on the farmland is believed to control crop weeds, pests, and disease. People view climatic change as acts of God and believe in God's intervention as traditional adaptation strategy(Batta et al., 2013). 
Creative commons User License: CC BY-NC-ND

Abstracted by: EBSCOhost, Electronic Journals Service (EJS),

Google Scholar, Journal Seek, Scientific Commons,

Food and Agricultural Organization (FAO), CABI and Scopus
Journal of Agricultural Extension

Vol. 22 (1) February, 2018

ISSN(e): 24086851; ISSN(Print); 1119944X

http://journal.aesonnigeria.org

http://www.ajol.info/index.php/iae

Email: editorinchief@aesonnigeria.org

\section{Table 4: Soil fertility increment and pest and disease control methods}

\begin{tabular}{|c|c|c|c|}
\hline \multirow[b]{2}{*}{ Discussed issues } & \multicolumn{2}{|c|}{ Responses } & \multirow[t]{2}{*}{ Agro -ecology } \\
\hline & Female FGDs & Male FGDs & \\
\hline & & & Highland \\
\hline \multirow[t]{5}{*}{ Soil fertility increment } & Crop rotation & Crop rotation & \\
\hline & $\begin{array}{l}\text { Changing other types of seed produced } \\
\text { from another farm }\end{array}$ & Terracing to deposit sediment soil & \\
\hline & & Using compost & \\
\hline & Frequent ploughing & & \\
\hline & Using compost & 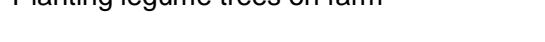 & \\
\hline \multirow[t]{3}{*}{ Crop pest control } & Spraying holy water on the crop farm & Spraying holy water on the crop farm & \\
\hline & using a mix of wood ash and leaves & Using livestock urine & \\
\hline & $\begin{array}{l}\text { Using smoke, Clearing farmlands and its } \\
\text { round }\end{array}$ & & \\
\hline \multirow[t]{4}{*}{ Crop weed control } & Hand weeding & Hand weeding & \\
\hline & Frequent ploughing & Frequent ploughing & \\
\hline & $\begin{array}{l}\text { Flooding to the farm (watering more water } \\
\text { to kill pests ) }\end{array}$ & Clearing farmlands and its round & \\
\hline & Sowing seeds in mud farm & & \\
\hline \multirow[t]{5}{*}{ Soil fertility increment } & Planting legume crops & Crop rotation (legume crops) & Midland \\
\hline & Using compost & Livestock urine, compost & \\
\hline & Immature weed (green manure) & Frequent ploughing & \\
\hline & Terracing to deposit organic sediment & Planting legume plants on farm & \\
\hline & & Terracing, Grass strips & \\
\hline \multirow[t]{4}{*}{ Crop pest control } & Using livestock urine to kill locusts & Clearing farmland and its round & \\
\hline & Hand weeding & Hand weeding & \\
\hline & Sowing seeds in mud farm & Frequent ploughing & \\
\hline & Clearing farmland and its round & & \\
\hline \multirow[t]{2}{*}{ Soil fertility increment } & Using compost & Crop rotation, Livestock urine & lowland \\
\hline & Using livestock urine & $\begin{array}{l}\text { Using compost, Immature weed (green } \\
\text { manure) }\end{array}$ & \\
\hline Crop pest control & $\begin{array}{l}\text { Spraying holy water on the crop farm and } \\
\text { Hoeing }\end{array}$ & $\begin{array}{l}\text { Spraying holy water on the crop farm, and } \\
\text { using livestock urine }\end{array}$ & \\
\hline \multirow[t]{3}{*}{ Crop weed control } & Hand weeding & Hand weeding & \\
\hline & Frequent ploughing & Frequent ploughing & \\
\hline & Hoeing & Clearing farmland and its round & \\
\hline
\end{tabular}

Focus group discussions (FGDs) data, August (2016) 
Creative commons User License: CC BY-NC-ND

Abstracted by: EBSCOhost, Electronic Journals Service (EJS),

Google Scholar, Journal Seek, Scientific Commons,

Food and Agricultural Organization (FAO), CABI and Scopus
Journal of Agricultural Extension

Vol. 22 (1) February, 2018

ISSN(e): 24086851; ISSN(Print); $1119944 X$

http://journal.aesonnigeria.org

http://www.ajol.info/index.phpliae

Email: editorinchief@aesonnigeria.org

\section{Conclusion and Recommendations}

Weather and seasonal forecasting, soil fertility increment techniques, pest, disease, and weed control methods and food shortage coping methods like seasonal migration and shift to cheap food items were some of the indigenous knowledge used by rural communities. However, it is important to know that not all indigenous practices are sustainable and not all local knowledge can provide the right solution for a given problem. For example, burning of residuals which was one of the traditional weed control techniques in the local community has contribution to enhance climate change. Therefore, before adopting such indigenous knowledge, integrating it into development programs, practices need to be examined for their appropriateness just as any other technology.

Not all households have the same levels and types of indigenous knowledge to combat the changing environment rather the knowledge is at community level. Therefore, institutional supports, as well as increased access to information, awareness creation through environmental education, and experience sharing among community members are important in increasing the application of indigenous knowledge to combat climate change impacts.

Except manure-compost, all other methods of indigenous knowledge practices were not supported by government and other stakeholders who are working on the agriculture sector. Participatory community consultations through government extension agents could help to develop sustainable alternatives to replace ineffective or unsustainable adaptation practices. Thus, bottom-up participatory approach should be implemented to encourage the highest level of community participation in combating climate change impacts. This bottom-up approach provides valuable insights into how rural communities interact and share ideas and allows developing the skills and practices necessary to frame their own path and increase their agricultural production in a sustainable way. Incorporating local knowledge into climate change policies can lead to the development of effective and sustainable adaptation strategies that are cost-effective and environment friendly.

\section{Acknowledgments}

This study was sponsored by the Pan African University (PAU) a continental initiative of the African Union Commission (AU), Addis Ababa, Ethiopia. The author acknowledges Professor Johnson $O$. Ayoade, Dr. Ibidun O. Adelekan and, Dr. Menberu Teshome Zeleke for their contribution to supervise the project from inception to end. Further, the author thanks the University of Ibadan for hosting the programme.

\section{Competing interests}

The author declares he has no competing interests

\section{References}

Ajani, E., Mgbenka, R. \& Okeke, M. 2013. Use of indigenous knowledge as a strategy for climate change adaptation among farmers in sub-Saharan Africa: Implications for policy. 
Creative commons User License: CC BY-NC-ND

Abstracted by: EBSCOhost, Electronic Journals Service (EJS),

Google Scholar, Journal Seek, Scientific Commons,

Food and Agricultural Organization (FAO), CABI and Scopus
Journal of Agricultural Extension

Vol. 22 (1) February, 2018

ISSN(e): 24086851; ISSN(Print); 1119944X

http://journal.aesonnigeria.org

http://www.ajol.info/index.php/jae

Email: editorinchief@aesonnigeria.org

Amare, Z., Ayoade, J., Adelekan, I. \& Zeleke, M. 2017. Climatic Variations, Trends and Drought Frequency in Dejen District, Nile Basin of Ethiopia. Journal of Applied science and Environmental management 21(7).

Amare, Z. Y. 2014. The role of Biogas Energy Production and Use in Greenhouse Gas Emission Reduction; the case of Amhara National Regional State, Fogera District, Ethiopia. Multidisciplinary Engineering Science and Technology 1, ISSN: 3159-0040.

Ayoade, J. 1983. Introduction to Climatology for the Tropics, Reprinted 2011, ISBN:978-978029-373-4, John Willey,London.

Batta, H. E., Ashong, A. C. \& Bashir, A. S. 2013. Press coverage of climate change issues in Nigeria and implications for public participation opportunities, ISSN 1913-9063 Journal of sustainable development, 6, 56-69.

Chang'a, L. B., Yanda, P. Z. \& Ngana, J. 2010. Indigenous knowledge in seasonal rainfall prediction in Tanzania: A case of the South-western Highland of Tanzania. Journal of Geography and Regional Planning, 3(4), 66-72.

Corbeels, M., Shiferaw, A. \& Haile, M. 2000. Farmers' knowledge of soil fertility and local management strategies in Tigray, Ethiopia, IIED-Drylands Programme.

DDEPO 2016. Dejen District Environmental Protection Office(DDEPO),Annual report. East Gojjam zone, Dejen, Ethiopia.

DDFEDO 2014. Dejen District Finance and Economic Development office, population projection

Demeke, A. B., Keil, A. \& Zeller, M. 2011. Using panel data to estimate the effect of rainfall shocks on smallholders food security and vulnerability in rural Ethiopia. Climatic change, 108, 185-206.

Deugd, M., Röling, N. \& Smaling, E. M. 1998. A new praxeology for integrated nutrient management, facilitating innovation with and by farmers. Agriculture, ecosystems \& environment, 71, 269-283.

Egeru, A. 2012. Role of indigenous knowledge in climate change adaptation: A case study of the Teso Sub-Region, Eastern Uganda. Indian Journal of Traditional Knowledge 11, 217-224.

Gray, C. \& Mueller, V. 2012. Drought and population mobility in rural Ethiopia. World development, 40, 134-145.

Heltberg, R., Siegel, P. B. \& Jorgensen, S. L. 2009. Addressing human vulnerability to climate change: toward a 'no-regrets' approach. Global Environmental Change, 19, 89-99.

IPCC 2007. Contribution of working group I to the fourth assessment report of the intergovernmental panel on climate change, 2007. Cambridge University Press, Cambridge.

Karjalainen, T., Kellomäki, S. \& Pussinen, A. 1994. Role of wood-based products in absorbing atmospheric carbon.

Mahoo, H., Mbungu, W., Yonah, I., Radeny, M., Kimeli, P. \& Kinyangi, J. 2015. Integrating indigenous knowledge with scientific seasonal forecasts for climate risk management in Lushoto district in Tanzania.

Nakashima, D. J., McLean, K. G., Thulstrup, H., Castillo, A. R. \& Rubis, J. T. 2012. Weathering uncertainty: traditional knowledge for climate change assessment and adaptation. Paris and Darwin: UNESCO and UNU.

Osunade, M. A. 1994. Indigenous climate knowledge and agricultural practice in Southwestern Nigeria. Malaysian journal of tropical geography.

Reijntjes, C., Haverkort, B. \& Waters, B. 1992. Farming for the future: an introduction to lowexternal-input and sustainable agriculture, Macmillan.

Risiro, J., Mashoko, D., Tshuma, T. \& Rurinda, E. 2012. Weather forecasting and indigenous knowledge systems in Chimanimani District of Manicaland, Zimbabwe. Journal of Emerging Trends in Educational Research and Policy Studies, 3, 561. 
Creative commons User License: CC BY-NC-ND

Abstracted by: EBSCOhost, Electronic Journals Service (EJS),

Google Scholar, Journal Seek, Scientific Commons,

Food and Agricultural Organization (FAO), CABI and Scopus

\section{Journal of Agricultural Extension}

Vol. 22 (1) February, 2018

ISSN(e): 24086851; ISSN(Print); 1119944X

http://journal.aesonnigeria.org

http://www.ajol.info/index.php/jae

Email: editorinchief@aesonnigeria.org

Schafer, J. W., Slikkeveer, D. \& LJ Titilola, S. 1989. Utilizing indigenous agricultural knowledge in the planning of agricultural research projects designed to aid small-scale farmerslndigenous knowledge systems: implications for agriculture and international development. lowa State Univ., Ames (EUA). Technology and Social Change Program Academy for Educational Development, Inc., Washington, DC (EUA).

Scott, J., Webber, B., Murphy, H., Ota, N., Kriticos, D. \& Loechel, B. 2014. AdaptNRM Weeds and climate change: supporting weed management adaptation. CSIRO, Canberra, www. AdaptNRM. org.

Slegers, M. F. \& Stroosnijder, L. 2008. Beyond the desertification narrative: a framework for agricultural drought in semi-arid East Africa. AMBIO: A Journal of the Human Environment, 37, 372-380.

Stainback, G. A. \& Alavalapati, J. R. 2002. Economic analysis of slash pine forest carbon sequestration in the southern US. Journal of Forest Economics, 8, 105-117.

Zhang, J., Frielinghaus, M., Tian, G. \& Lobb, D. A. 2004. Ridge and contour tillage effects on soil erosion from steep hillslopes in the Sichuan Basin, China. Journal of soil and water conservation, 59, 277-284.

Zhang, J., Su, Z. \& Nie, X. 2009. An investigation of soil translocation and erosion by conservation hoeing tillage on steep lands using a magnetic tracer. Soil and Tillage Research, 105, 177-183.

Ziervogel, G. \& Opere, A. 2010. Integrating meteorological and indigenous knowledge-based seasonal climate forecasts for the agricultural sector: Lessons from participatory action research in sub-Saharan Africa. 